The Canadian Mineralogist

Vol. 41, pp. 529-540 (2003)

\title{
BROMINE IN SCAPOLITE-GROUP MINERALS AND SODALITE: XRF MICROPROBE ANALYSIS, EXCHANGE EXPERIMENTS, AND APPLICATION TO SKARN DEPOSITS
}

\author{
YuANMING PAN ${ }^{\S}$ AND PING DONG \\ Department of Geological Sciences, University of Saskatchewan, Saskatoon, Saskatchewan S7N 5E2, Canada
}

\begin{abstract}
Application of an X-ray fluorescence (XRF) microprobe for the analysis of single grains (80 to $1,000 \mu \mathrm{m}$ in diameter) of Clrich minerals for $\mathrm{Br}$ has been evaluated for fluorapatite, chlorapatite, scapolite-group minerals (marialite and meonite) and sodalite. A calibration curve based on the $\mathrm{Br}$ contents in four international reference materials has been confirmed by measurements on $\mathrm{Br}$ bearing standard solutions and by agreement with the results of $\mathrm{Cl}$-rich minerals from instrumental neutron-activation analyses. Absolute errors associated with individual XRF microprobe analyses (i.e., counting statistics alone) are less than 5\%, and the calculated limit of detection in the analysis of single mineral grains is $\sim 1 \mathrm{ppm} \mathrm{Br}$. Matrix and grain-size effects are shown to be negligible. Experiments at 1 atmosphere and 800 to $1000^{\circ} \mathrm{C}$ yield the following distribution coefficients for $\mathrm{Br}-\mathrm{Cl}$ exchanges between marialite or sodalite and hydrous $\mathrm{NaCl}-\mathrm{NaBr}$ melts: $\mathrm{K}_{\mathrm{D}}{ }^{\text {marialite-melt }}=0.97 \pm 0.08$ and $\mathrm{K}_{\mathrm{D}}{ }^{\text {sodalite-melt }}=0.9 \pm 0.1$. Therefore, the $\mathrm{Cl} / \mathrm{Br}$ values in marialite and sodalite closely reflect the halogen proportions of their coexisting melts or fluids. The diffusivity of $\mathrm{Br}$ in sodalite follows an Arrhenius relation: $\mathrm{D}_{\mathrm{Br}}=6.5 \times 10^{-7} \exp (-270 \pm 10 \mathrm{~kJ} / \mathrm{mol} / \mathrm{RT}) \mathrm{m}^{2} / \mathrm{s}$, over the temperature range from 800 to $1000^{\circ} \mathrm{C}$. $\mathrm{D}_{\mathrm{Br}}$ in marialite is $1.7 \pm 0.3 \times 10^{-19} \mathrm{~m}^{2} / \mathrm{s}$ at $800^{\circ} \mathrm{C}$. The $\mathrm{Cl} / \mathrm{Br}$ weight ratios of marialite in the Tieshan Fe skarn deposit, China, cluster around $650 \pm 40$, supporting an origin involving hydrothermal brines from associated evaporites. Scapolitegroup minerals in the exoskarns of the Nickel Plate Au skarn deposit, British Columbia, have $\mathrm{Cl} / \mathrm{Br}$ from 560 to 570, higher than those (130 to 180) of their counterparts in the endoskarns and vuggy cavities. This variation is attributable to an increased involvement of magmatic water from distal to proximal zones. Similarly, scapolite-group minerals in the Grenville U-Th-Mo$R E E$ pegmatite-skarn-vein deposits vary widely in $\mathrm{Cl} / \mathrm{Br}$, from 80 to 380, indicative of mixed sources of hydrothermal fluids. This study shows the potential of $\mathrm{Br}$ analysis of $\mathrm{Cl}$-rich silicate minerals for constraining the sources and evolution of hydrothermal fluids.
\end{abstract}

Keywords: XRF microprobe, Br, scapolite-group minerals, sodalite, exchange experiments, distribution coefficient, diffusion coefficient, skarn deposits.

\section{SOMMAIRE}

Nous évaluons l'application d'une microsonde à fluorescence X pour l'analyse de grains isolés (de 80 à $1,000 \mu \mathrm{m}$ de diamètre) pour le $\mathrm{Br}$ dans les minéraux porteurs de $\mathrm{Cl}$ comme la fluorapatite, la chlorapatite, les minéraux du groupe de la scapolite tels marialite et méionite, et sodalite. Le calibrage a été fait au moyen des teneurs en brome de quatre étalons internationaux, et a été confirmé avec des résultats obtenus pour des solutions standards contenant du $\mathrm{Br}$ et des minéraux riches en $\mathrm{Cl}$ analysés par activation neutronique instrumentale. Les erreurs absolues associées à une seule analyse par microsonde à fluorescence X, dues aux seules erreurs de comptage, sont inférieures à 5\%, et le seuil de détection calculé est d'environ $\sim 1 \mathrm{ppm}$ Br. Les effets de matrice et dus à la taille des grains sont négligeables. Des expériences à 1 atmosphère et entre 800 et $1000^{\circ} \mathrm{C}$ ont donné les coefficients de distribution suivants pour l'échange $\mathrm{Br}-\mathrm{Cl}$ entre marialite ou sodalite et un bain fondu hydraté $\mathrm{NaCl}-\mathrm{NaBr}$ : $\mathrm{K}_{\mathrm{D}}{ }^{\text {marialite-bain fondu }}=0.97 \pm 0.08$ et $\mathrm{K}_{\mathrm{D}}{ }^{\text {sodalite-bain fondu }}=0.9 \pm 0.1$. C'est donc dire que le rapport $\mathrm{Cl} / \mathrm{Br}$ dans la marialite et la sodalite s'approchent étroitement des proportions de ces halogènes dans les bains fondus (ou fluides) coexistants. La diffusivité du Br dans la sodalite répond à une relation de type Arrhenius: $\mathrm{D}_{\mathrm{Br}}=6.5 \times 10^{-7} \exp (-270 \pm 10 \mathrm{~kJ} / \mathrm{mol} / \mathrm{RT}) \mathrm{m}^{2} / \mathrm{s}$, sur un intervalle de température entre 800 et $1000^{\circ} \mathrm{C}$. $\mathrm{D}_{\mathrm{Br}}$ pour la marialite est $1.7 \pm 0.3 \times 10^{-19} \mathrm{~m}^{2} / \mathrm{s}$ à $800^{\circ} \mathrm{C}$. Les valeurs du rapport pondéral $\mathrm{Cl} / \mathrm{Br}$ de la marialite provenant du gisement de fer de type skarn à Tieshan, en Chine, se regroupent autour de $650 \pm 40$, et étayent l'hypothèse d'une origine impliquant des saumures issues d'une séquence d'évaporites associée. Les minéraux du groupe de la scapolite des exoskarns du gisement aurifère de Nickel Plate, en Colombie-Britannique, possèdent des valeurs de $\mathrm{Cl} / \mathrm{Br}$ entre 560 et 570, plus élevées que celles de l'endoskarn et des cavités (entre 130 et 180). Cette variation laisse entrevoir une implication accrue d'une phase fluide orthomagmatique à mesure que l'on s'approche du gisement. De même, dans les minéraux du groupe de la scapolite des pegmatites, skarns et veines à U-Th-Mo-REE de la Province du Grenville, le rapport $\mathrm{Cl} / \mathrm{Br}$ varie beaucoup,

§E-mail address: yuanming.pan@usask.ca 
de 80 à 380, indication de sources mixtes des fluides hydrothermaux. Les analyses pour le $\mathrm{Br}$ des silicates porteurs de $\mathrm{Cl}$ ont le potentiel de cerner la source des fluides hydrothermaux et d'en définir l'évolution.

(Traduit par la Rédaction)

Mots-clés: microsonde à fluorescence X, brome, minéraux du groupe de la scapolite, sodalite, échange par voie expérimentale, coefficient de distribution, coefficient de diffusion, skarn, gisements.

\section{INTRODUCTION}

Halogens ( $\mathrm{F}, \mathrm{Cl}, \mathrm{Br}$ and $\mathrm{I})$ are common constituents in igneous, metamorphic and sedimentary rocks, and are particularly abundant in the hydrosphere. Knowledge of the halogens in geological samples is important in our understanding of magmatic, metamorphic and sedimentary processes (e.g., Sigiura et al. 1963, Böhlke \& Irwin 1992, Carroll \& Webster 1994, You et al. 1994, McCaig et al. 2000), in the formulation of genetic models for mineral deposits (e.g., Kesler et al. 1995, Markl \& Piazolo 1998) and in the reconstruction of paleoenvironments (e.g., Channer et al. 1997, Siemann \& Schramm 2002). There is a considerable body of data on $\mathrm{F}$ and $\mathrm{Cl}$ in rocks, minerals, melts and fluids (Böhkle \& Irwin 1992, Carroll \& Webster 1994, and references therein). However, data of $\mathrm{Br}$ and I in minerals, except for those in halides (e.g., Stoessell \& Carpenter 1986, Raup \& Hite 1996), are scarce because of analytical difficulties for these elements (e.g., Heumann et al. 1987, Boneß et al. 1991, Shinonaga et al. 1994, O’Reilly \& Griffin 2000).

In this contribution, we report on results of an analysis of Cl-rich minerals for $\mathrm{Br}$ by use of an energy-dispersion miniprobe multi-element analyzer [EMMA or $\mathrm{X}$-ray fluorescence (XRF) microprobe; Cheburkin et al. 1997]. A major feature of this XRF microprobe is the use of monochromatic X-ray radiation $(17.44 \mathrm{keV}$, $\mathrm{MoK \alpha}$ ) for excitation, which results in a much lower background than with conventional XRF instruments, and allows the direct analysis of single grains of minerals and solutions for a suite of trace elements (Cheburkin et al. 1997). Our main objectives in this study are: 1) to evaluate the application of XRF microprobe for analysis of Cl-rich minerals (including fluorapatite, chlorapatite, marialite and sodalite) for $\mathrm{Br}, 2)$ to determine factors controlling the $\mathrm{Cl} / \mathrm{Br}$ values in scapolite-group minerals and sodalite by ion-exchange experiments, and 3 ) to document and interpret the $\mathrm{Cl} / \mathrm{Br}$ values in scapolitegroup minerals from selected skarn-type deposits [i.e., the Tieshan Fe deposit, Hubei Province, China: Pan \& Dong (1999), the Nickel Plate Au deposit of British Columbia: Pan et al. (1994), and the U-Th-Mo-REE deposits of the Grenville Province, Ontario and Quebec: Lentz (1992, 1998, and references therein)].

\section{XRF Microprobe, SAMPLES, Analytical Procedures and ExPERIMENTS}

\section{$X$-ray fluorescence microprobe}

The instrument design and operation of the energydispersion miniprobe multi-element analyzer (EMMA or XRF microprobe), housed at the University of Saskatchewan (U of SK), have been described in Cheburkin et al. (1997). Briefly, the XRF microprobe consists of a conventional $2.0 \mathrm{~kW} \mathrm{X-ray} \mathrm{generator,} \mathrm{a}$ concave (Johansson) LiF (220) $(\mathrm{R}=250 \mathrm{~mm})$ monochromator, a sample holder attached to a conventional optical microscope, and an energy-dispersion X-ray spectrometer. The spectrometer consists of a $28 \mathrm{~mm}^{2}$ $\mathrm{Si}(\mathrm{Li})$ detector, a pulse amplifier, a 12-bit analogue-todigital converter and an interface card; it is controlled by an IBM-compatible computer. The X-ray generator is operated at a voltage of $45 \mathrm{kV}$ and a current of 20 $\mathrm{mA}$. The X-ray beam $(0.1 \times 2.5 \mathrm{~mm})$ is focused from the $\mathrm{LiF}$ monochromator, and is collimated by a conical collimator of $0.2 \times 2.5 \mathrm{~mm}$ in dimension. Data acquisition and processing were made on computer programs provided by EMMA Analytical Inc. (Cheburkin et al. 1997).

The U of SK XRF microprobe has been calibrated for the following elements: $\mathrm{As}, \mathrm{Br}, \mathrm{Cr}, \mathrm{Cu}, \mathrm{Fe}, \mathrm{Ga}, \mathrm{Ge}$, $\mathrm{Hf}, \mathrm{Mn}, \mathrm{Ni}, \mathrm{Rb}, \mathrm{Se}, \mathrm{Sr}, \mathrm{Th}, \mathrm{U}$, and $\mathrm{Zn}$ using selected international reference materials (Govindaraju 1994). For example, a calibration curve for $\mathrm{Br}$ was established on the basis of four international reference materials (LKSD-1: 11 ppm Br, LKSD-4: 49 ppm, NBS1646: 117 ppm, and MAG-1: 252 ppm; Govindaraju 1994). In this study, a suite of Cl-rich minerals (fluorapatite, chlorapatite, marialite and sodalite, Table 1) from the U of SK reference collection was used to further evaluate this calibration. These minerals, selected on the basis of quantitative electron-microprobe analyses (EMPA) for their homogeneity in $\mathrm{Cl}$ and other major elements, were crushed to 100-140 mesh (106-125 $\mu \mathrm{m})$, and were hand-picked under a binocular microscope to minimize mineral and fluid inclusions. These separates $(\sim 0.5 \mathrm{~g}$ each) were sent to the Activation Laboratories of Ancaster, Ontario, for instrumental neutron-activation analysis (INAA) for Br. Also, five solutions with 2, 5, 
TABLE 1. DESCRIPTION OF MINERAL STANDARDS AND SCAPOLITE-GROUP MINERALS IN SKARN DEPOSITS

\begin{tabular}{|c|c|c|c|c|}
\hline Number & Mineral & Location & Description & Ref. \\
\hline AP-1 & fluorapatite & Durango, Mexico & fluorapatite crystals & 1 \\
\hline AP-2 & chlorapatite & Bob's Lake, Ontario & chlorapatite crystals & 1 \\
\hline SCP-1 & marialite & Gooderham, Ontario & marialite crystals in a pegmatitic skarn & $1^{*}$ \\
\hline SCP-2 & marialite & Haliburton, Ontario & marialite crystals in skarn & 1 \\
\hline $\mathrm{SCP}-3$ & marialite & Bancroft, Ontario & marialite crystals in marble & 1 \\
\hline SOD-1 & sodalite & Bancroft, Ontario & sodalite-rich rock & 1 \\
\hline SOD-2 & sodalite & Ice River, British Columbia & sodalite-rich rock & 1 \\
\hline SOD-3 & sodalite & South Africa & sodalite-rich rock & 1 \\
\hline $99-1-3$ & scapolite & Tieshan, Daye, Hubei, China & endoskarn & 2 \\
\hline $99-1-5$ & scapolite & Tieshan, Daye, Hubei, China & endoskarn & 2 \\
\hline $99-1-9$ & scapolite & Tieshan, Daye, Hubei, China & Scp-Cpx endoskarn & 2 \\
\hline $99-1-12$ & scapolite & Tieshan, Daye, Hubei, China & Scp endoskarn & 2 \\
\hline $99-1-14$ & scapolite & Tieshan, Daye, Hubei, China & Scp-Phl-Cpx-Mt endoskarn & 2 \\
\hline $99-1-16$ & scapolite & Tieshan, Daye, Hubei, China & Scp-Phl-Cpx endoskarn & 2 \\
\hline $99-1-17$ & scapolite & Tieshan, Daye, Hubei, China & Scp-Phl-Cpx-Grt endoskarn & 2 \\
\hline $99-1-19$ & scapolite & Tieshan, Daye, Hubei, China & Scp-Grt-Cpx endoskarn & 2 \\
\hline $99-1-20$ & scapolite & Tieshan, Daye, Hubei, China & Scp-Cpx endoskarn & 2 \\
\hline $99-1-22$ & scapolite & Tieshan, Daye, Hubei, China & Scp-Cpx endoskarn & 2 \\
\hline $401-9$ & scapolite & Nickel Plate, British Columbia & endoskarn & 3 \\
\hline $401-12$ & scapolite & Nickel Plate, British Columbia & endoskarn & 3 \\
\hline $263-13$ & scapolite & Nickel Plate, British Columbia & exoskarn & 3 \\
\hline $73-1-8$ & scapolite & Nickel Plate, British Columbia & exoskarn & 3 \\
\hline HD55 & scapolite & Nickel Plate, British Columbia & vuggy cavity, Copperfield breccia & 3 \\
\hline DL-22B & scapolite & Clark fluorite pegmatite/skarn & Fl-Cpx-Scp-Kfs skarn near pegmatite & 4 \\
\hline DL-26A & scapolite & McDonald feldspar pegmatite & Phl-Cpx-Scp-Cc skarn near pegmatite & 4 \\
\hline DL-28A & scapolite & Quirk U pegmatite/skarn & Cpx-Scp skarn near pegmatite & 4 \\
\hline DL-30A & scapolite & Cardiff North Zone U skarn & Cpx-Scp-Phl-Ce skarn & 4 \\
\hline DL-45D & scapolite & Belanger's Corner Zone & Phl-Cpx-Scp skarn & 4 \\
\hline DL-60A & scapolite & Matte apatite-U vein & Cpx-Fl-FAp-Cc vein (Scp-Cpx margin) & 4 \\
\hline DL-60G & scapolite & Matte apatite-U vein & Cpx-Fl-FAp-Cc vein (Scp-Cpx margin) & 4 \\
\hline DL-61A & scapolite & Camp pegmatite/skarn/vein & Phl-Tr-Scp skarn near pegmatite & 4 \\
\hline DL-62C & scapolite & Thorianite skarn & Cpx-Phl-Cc skarn & 4 \\
\hline DL-66H & scapolite & Calumet U skarn/vein & Py-Phl-Cc-Scp-Cpx skarn near dike & 4 \\
\hline DL-70K & scapolite & Litchfield Mo skarn/vein & Ttn-Phl-Scp-Cc skarn vein & 4 \\
\hline DL-70N & scapolite & Litchfield Mo skarn/vein & Phl-Scp-Ce skarn & 4 \\
\hline
\end{tabular}

Reference 1 U of Saskatchewan reference mineral collection, 2 Pan \& Dong (1999), 3 Pan et al. (1994), 4 Lentz (1992). Mineral abbreviations: Cc calcite, Cpx clinopyroxene, FAp fluorapatite, Fl fluorite, Grt garnet, Kfs Kfeldspar, Phl phlogopite, Py pyrite, Scp scapolite-group minerais (undifferentiated), Tr tremolite, and Ttn titanite *: sample SCP-1 is ON8 of Shaw (1960) and Teertstra \& Sherriff (1997).

10, 50 and $100 \mathrm{ppm} \mathrm{Br}$ were prepared volumetrically from $\mathrm{NaBr}$ (Aldrich \#22,988-1) and ultra-pure, deionized water, and were analyzed with the XRF microprobe (Table 2).

\section{Samples of scapolite-group minerals from skarn deposits}

Details of samples of the scapolite-group minerals from the Tieshan Fe skarn deposit, Hubei Province, China (Pan \& Dong 1999), the Nickel Plate Au skarn deposit, British Columbia (Pan et al. 1994), and the UTh-Mo-REE deposits of the Grenville Province, Ontario and Quebec (Lentz 1992, 1998) are given in Table 1. Grains of scapolite-group minerals from these skarn deposits were hand-picked from powdered rock samples (Tieshan) or mineral separates (Grenville) under a binocular microscope, and were further examined on a petrographic microscope at high magnifications $(250 \times$ to $450 \times)$ to minimize mineral impurities and fluid inclusions. The Nickel Plate grains were removed from polished thin sections after petrographic observa-
TABLE 2. PRECISION AND ACCURACY OF ANALYSIS FOR Br BY XRF MICROPROBE

\begin{tabular}{|c|c|c|c|c|c|c|c|c|}
\hline \multirow[b]{2}{*}{ Sample } & \multicolumn{4}{|c|}{ Precision } & \multicolumn{4}{|c|}{ Accuracy } \\
\hline & $\begin{array}{c}\mathrm{Br} \\
\mathrm{ppm}\end{array}$ & $\begin{array}{c}\text { XRFM } \\
n=6\end{array}$ & $\underset{\sigma}{\mathrm{SD}}$ & $\underset{\%}{\mathrm{RSD}}$ & $\begin{array}{c}\text { XRFM } \\
n=16\end{array}$ & $\begin{array}{c}\mathrm{SD} \\
\sigma\end{array}$ & $\begin{array}{c}\mathrm{RSD} \\
\%\end{array}$ & $\underset{\%}{\text { DIFF }}$ \\
\hline $\begin{array}{l}\text { AP-1 } \\
\text { AP-2 } \\
\text { SCP-1 } \\
\text { SCP-2 } \\
\text { SCP-3 } \\
\text { SOD-1 } \\
\text { SOD-2 } \\
\text { SOD-3 }\end{array}$ & $\begin{array}{r}8^{\dagger} \\
75 \\
42 \\
115 \\
70 \\
234 \\
301 \\
418\end{array}$ & $\begin{array}{c}7.8 \\
74 \\
41 \\
114 \\
75 \\
221 \\
283 \\
395\end{array}$ & $\begin{array}{l}0.8 \\
4 \\
2 \\
5 \\
3 \\
8 \\
11 \\
12\end{array}$ & $\begin{array}{r}10.2 \\
5.4 \\
4.9 \\
4.4 \\
4.0 \\
3.6 \\
3.9 \\
3.0\end{array}$ & $\begin{array}{c}7.6 \\
64 \\
41 \\
114 \\
75 \\
223 \\
284 \\
395\end{array}$ & $\begin{array}{c}1.2 \\
12 \\
2 \\
9 \\
3 \\
11 \\
13 \\
16\end{array}$ & $\begin{array}{c}16 \\
19 \\
4.9 \\
7.9 \\
4.2 \\
4.9 \\
4.6 \\
4.1\end{array}$ & $\begin{array}{l}-5.0 \\
-12 \\
-2.1 \\
-1.0 \\
+7.1 \\
-4.7 \\
-5.6 \\
-5.5\end{array}$ \\
\hline $\begin{array}{l}\text { Water-1 } \\
\text { Water-2 } \\
\text { Water-3 } \\
\text { Water-4 } \\
\text { Water-5 }\end{array}$ & $\begin{array}{r}2^{\ddagger} \\
5 \\
10 \\
50 \\
100\end{array}$ & & & & $\begin{array}{c}2.9 \\
5.6 \\
9.6 \\
51 \\
107\end{array}$ & $\begin{array}{l}0.2 \\
0.3 \\
0.8 \\
1.9 \\
3.4\end{array}$ & $\begin{array}{l}6.9 \\
5.9 \\
8.3 \\
3.7 \\
3.2\end{array}$ & $\begin{array}{l}+45 \\
+12 \\
-4.0 \\
+2.0 \\
+7.0\end{array}$ \\
\hline
\end{tabular}

$\uparrow \mathrm{Br}$ contents of mineral separates determined by instrumental neutron-activation an deionized water: XRFM: X-ray fluorescence microprobe; SD: standard deviation (one sigma); RSD: relative standard deviation; DIFF: difference. 
tions and quantitative EMPA (see below), except that those of sample HD55 were taken directly from single crystals in a vuggy cavity (Pan et al. 1994). In general, three grains of scapolite-group minerals from each sample were analyzed with the XRF microprobe. However, 10 grains were examined for sample DL-70K from the Litchfield Mo skarn vein (Table 1), in which a large variation in $\mathrm{Br}$ was detected (see below).

\section{Exchange experiments}

Eight exchange experiments between minerals and hydrous halide-rich melts were made for a sample of marialite (SCP-1 from Gooderham, Ontario, $M e_{12.2}$ : Shaw 1960, Teertstra \& Sherriff 1997) and sodalite (SOD-3 from South Africa): using $\mathrm{NaCl}-\mathrm{NaBr}$ weight ratios of $1: 1$ and $2: 1$ and temperatures of 800 and $1000^{\circ} \mathrm{C}$. Each charge, comprising 0.02 g powdered marialite or sodalite grains, $0.08 \mathrm{~g} \mathrm{NaCl}-\mathrm{NaBr}$ mixture and $0.01 \mathrm{~g}$ deionized water, was sealed in Au or Pt capsules by welding. The experiments at $800^{\circ} \mathrm{C}$, using $\mathrm{Au}$ capsules, were performed in a Thermolyne 47900 furnace for 30 days and were quenched in water. The $1000^{\circ} \mathrm{C}$ experiments in $\mathrm{Pt}$ capsules, performed in a Thermolyne 46100 furnace, were planned for 14 days but terminated after 12 days owing to a power failure. The experimental products, after washing with deionized water, were mounted in Pyrex plugs and polished for electron-microprobe analysis.

\section{Electron-microprobe analysis}

After the XRF microprobe analysis, the grains of fluorapatite, chlorapatite, scapolite-group minerals (including those from the skarn deposits) and sodalite were mounted on Pyrex plugs, polished and carbon-coated for EMPA, with the exception of scapolite-group minerals from polished thin sections from the Nickel Plate deposit (samples 401-9, 401-12, 263-13 and 73-1-8). These were analyzed by EMPA before their removal. These analyses were performed on a JEOL JXA-8600 Superprobe equipped with three automated wavelengthdispersion and one energy-dispersion spectrometers at the U of SK. Operating conditions included: accelerating voltage $15 \mathrm{kV}$, beam current $10 \mathrm{nA}$, beam diameter $5 \mu \mathrm{m}$ and 20 second counting-time (excepting $60 \mathrm{~s}$ for $\mathrm{Fe}$ and $\mathrm{Sr}$ ). Standards included quartz $(\mathrm{Si})$, corundum $(\mathrm{Al})$, diopside $(\mathrm{Ca})$, jadeite $(\mathrm{Na})$, sanidine $(\mathrm{K})$, fayalite $(\mathrm{Fe})$, celestine $(\mathrm{Sr})$, tugtupite $(\mathrm{Cl})$ and anhydrite $(\mathrm{S})$. In addition, marialite ON-70 of Shaw (1960) was used as an independent standard.

Electron-microprobe analyses of ion-exchanged marialite and sodalite were made at an accelerating voltage of $10 \mathrm{kV}$, a beam current of $10 \mathrm{nA}$, a beam diameter of $\sim 1 \mu \mathrm{m}, 30$ s counting-time, and similar mineral standards as above, except that $\mathrm{KBr}$ was added as a standard for Br. The low accelerating voltage was used here to reduce the beam size (see below). Peak-overlap in- terference between $\mathrm{Al}$ and $\mathrm{Br}$ was corrected for manually, and was monitored by analyzing a synthetic crystal of end-member $\mathrm{Na}_{8}\left(\mathrm{Al}_{6} \mathrm{Ge}_{6}\right) \mathrm{O}_{24} \mathrm{Br}_{2}$ (Fleet 1989).

\section{Results AND Discussion}

\section{Quantitative analysis of Cl-rich minerals for $\mathrm{Br}$ by XRF microprobe}

Mineral grains selected for XRF microprobe analysis were placed in sample holders made of $4 \mu \mathrm{m}$ thick Prolene films. Counting times were 10 minutes for typical analyses of single grains, but were increased to 45 minutes for mineral grains that contain less than $10 \mathrm{ppm}$ $\mathrm{Br}$ or are smaller than $100 \mu \mathrm{m}$ in diameter. XRF microprobe analyses of the Br-bearing standard solutions were made on drops in similar sample holders, with counting times of 10 and 45 minutes for Br concentrations above and below $10 \mathrm{ppm}$, respectively.

Figure 1a shows that the $\mathrm{Br}$ contents in fluorapatite, chlorapatite, marialite and sodalite, obtained by the XRF microprobe technique, are in excellent agreement with

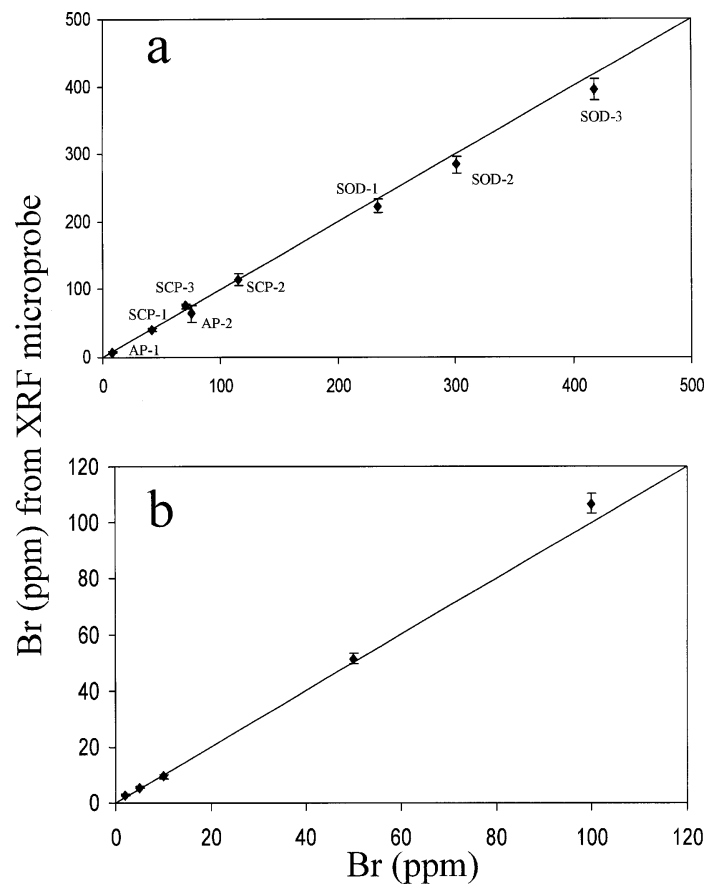

FIG. 1. Comparison of a) $\mathrm{Br}$ contents of fluorapatite, chlorapatite, marialite and sodalite obtained from XRF microprobe analysis and instrumental neutron-activation analysis (INAA) (see Table 1 for sample numbers; labeled), and $\mathrm{b}) \mathrm{Br}$ in standard solutions by XRF microprobe analysis. 
those from INAA on bulk mineral separates. The only exception is a large relative standard deviation (19\%) of the $\mathrm{Br}$ content in chlorapatite from Bob's Lake, Ontario, which is attributable to compositional heterogeneity related to the local presence of small patches of fluorapatite in this sample. Excellent agreement was also obtained for the Br-bearing standard solutions (Fig. 1b).

These results show that the XRF microprobe technique is capable of quantitative analysis of Cl-rich minerals for $\mathrm{Br}$, and that a matrix effect is negligible, at least for the minerals investigated in this study. This lack of a matrix effect is also evident in the successful analysis of the Br-bearing standard solutions (Fig. 1b), which uses the same calibration curve, based on the rock powders. However, a significant matrix effect of this XRF microprobe technique is known for some high-density minerals (e.g., monazite and zircon; Cheburkin et al. 1997). Analyses of marialite from sample SCP-3 (Table 1), with grain sizes in the range of 80 to $1,000 \mu \mathrm{m}$ in diameter, show that a grain-size effect also is negligible.

\section{Precision, accuracy and detection limit}

The precision, accuracy and detection limit of the XRF microprobe for the analysis of single mineral grains are all related to a number of variables, such as the grain size and the counting time. For example, the larger the grain size and the longer the counting time, the higher the count rates and the better the counting statistics, respectively, and hence, improved precision and detection limit. The following evaluation of precision, accuracy and detection limit was made for most analyses of mineral grains (i.e., for grains sizes of 100 to $500 \mu \mathrm{m}$ in diameter and counting times of 10 and 45 minutes for $\mathrm{Br}$ concentrations above and below $10 \mathrm{ppm}$, respectively). This protocol was used to ensure that the absolute errors associated with individual analyses (i.e., counting statistics alone) are less than 5\%.

Repeated analyses of selected grains of fluorapatite, marialite and sodalite were used to demonstrate the precision of the XRF microprobe technique (Table 2). Relative standard deviations (RSD) are generally less than $5 \%$ for $\mathrm{Br}$ concentrations above $10 \mathrm{ppm}$, but increase to about $10 \%$ for concentrations below $10 \mathrm{ppm}$ (Table 2). The accuracy of the XRF microprobe technique has been evaluated by comparison with the INAA results for fluorapatite, chlorapatite, marialite and sodalite (Table 2). The differences between the XRF microprobe and INAA results are $<10 \%$ for $\mathrm{Br}$ concentrations above $10 \mathrm{ppm}$ and $10-20 \%$ for concentrations from 2 to 10 ppm (Table 2). The largest difference $(+45 \%)$, for the standard solution containing $2 \mathrm{ppm} \mathrm{Br}$, may be attributable to significant evaporation because of a counting time of 45 minutes in this analysis. The detection limit (defined as three standard deviations of the background) of the XRF microprobe technique has been established for mineral grains (i.e., a quartz crystal annealed at $1500^{\circ} \mathrm{C}$ for 12 hours) as well as solution samples, and is approximately $1 \mathrm{ppm} \mathrm{Br}$.

\section{Bromine in Cl-rich minerals}

The presence of significant $\mathrm{Br}$ in halite and sylvite is well documented (e.g., Stoessell \& Carpenter 1986, Berndt \& Seyfried 1997). Appel (1997) reported high $\mathrm{Br}$ contents (up to $418 \mathrm{ppm}$ ) and low $\mathrm{Cl} / \mathrm{Br}$ values (down to 1.6) in hydrothermally altered Archean komatiitic rocks from West Greenland, and suggested that $\mathrm{Br}$ may originally reside in hydroxychlorides (e.g., hibbingite) or in fluid inclusions. It remains unclear whether the trace amounts of $\mathrm{Br}$ in nominally anhydrous silicate minerals (e.g., feldspars; Shinonaga et al. 1994) are or are not related to the presence of fluid inclusions in these minerals. O'Reilly \& Griffin (2000) reported up to 54 $\mathrm{ppm} \mathrm{Br}$ in fluorapatite from mantle xenoliths by laser ablation - inductively coupled plasma - mass spectrometry (see also Dong \& Pan 2002). INAA and XRF microprobe analyses in this study showed that the Durango fluorapatite contains $\sim 8 \mathrm{ppm} \mathrm{Br}$, whereas chlorapatite from Bob's Lake, Ontario, has a notably higher Br content (Table 2).

Scapolite-group minerals and sodalite of this study contain up to 144 and $395 \mathrm{ppm} \mathrm{Br}$, respectively (Tables $2,3 a, b, c)$. To the best of our knowledge, this is the first report of significant $\mathrm{Br}$ in natural $\mathrm{Cl}$-rich aluminosilicates. Bromine is known to strongly partition into aqueous fluids or melts rather than coexisting minerals (Seyfried et al. 1986), and in this way is similar to $\mathrm{Cl}$ (Carroll \& Webster 1994). Therefore, the presence of any fluid inclusions in selected mineral grains could significantly affect the analytical results concerning $\mathrm{Br}$. During the initial stage of this study, anomalously high (and variable) $\mathrm{Br}$ contents were encountered in a few grains of halite and were subsequently found to be related to the presence of fluid inclusions. Fortunately, fluid inclusions are generally rare in grains of scapolitegroup minerals (Pan et al. 1994). Also, care was taken in our selection of the mineral grains to minimize the effect of fluid inclusions and other impurities. On the basis of the mostly homogeneous distribution of $\mathrm{Br}$ in scapolite-group minerals, as evidenced by the small standard deviations (Table 3a, b, c), we suggest that the $\mathrm{Br}$ contents in scapolite-group minerals and sodalite of this study (Tables 2, 3a, b, c) represent a substitution for $\mathrm{Cl}$ in these minerals. This suggestion is supported by a correlation between the $\mathrm{Br}$ contents from the XRF microprobe analyses and the $\mathrm{Cl}$ contents from EMPA analysis in sample DL-70K (Table 3c).

\section{Results of exchange experiments and factors controlling the $\mathrm{Cl} / \mathrm{Br}$ values in marialite and sodalite}

The experimental products of all four runs on sodalite (Table 4) consist of sodalite, glass and water (at 
TABLE 3a. COMPOSITIONS OF SCAPOLITE-GROUP MINERALS FROM THE TIESHAN Fe SKARN DEPOSIT, CHINA

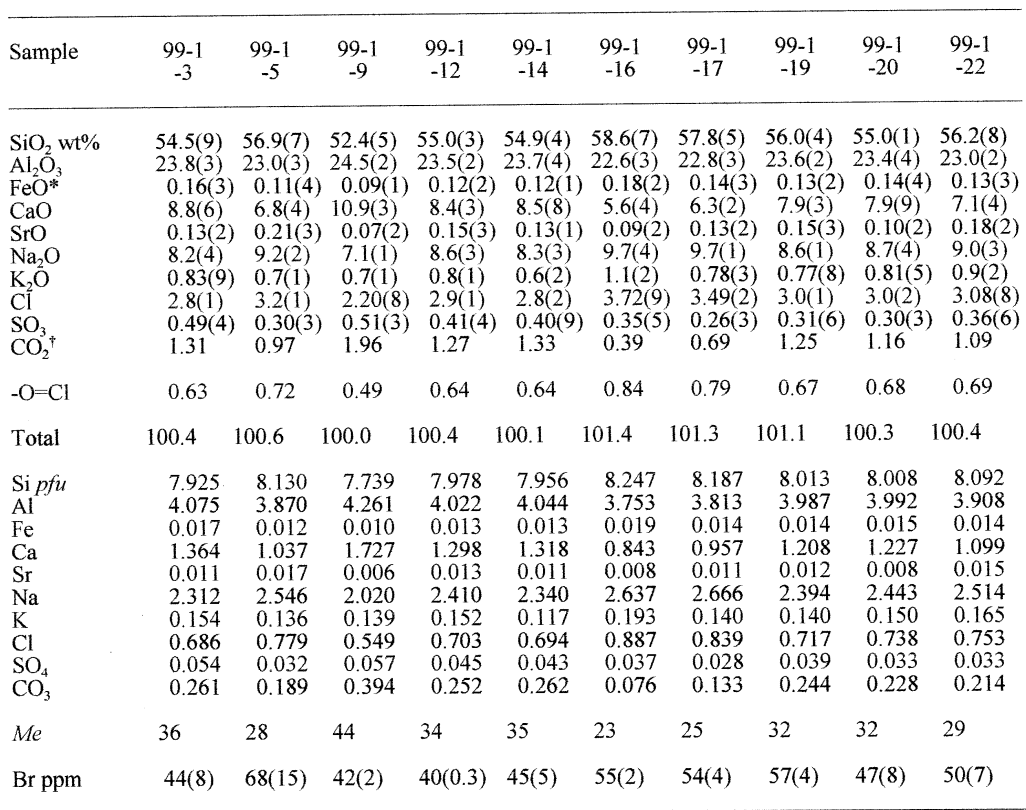

* total iron as $\mathrm{FeO} ;{ }^{\dagger}$ calculated on the basis of stoichiometry; $\mathrm{Me} ; 100(\mathrm{Ca}+\mathrm{Sr}) /(\mathrm{Ca}+\mathrm{Sr}+\mathrm{Na}+\mathrm{K}) ; p f u$ : proportion of atom or group per formula unit. Numbers in parentheses are standard deviations (one sigma).

room temperature). Similarly, marialite in experiments at $800^{\circ} \mathrm{C}$ is well preserved. However, marialite in the two runs at $1000^{\circ} \mathrm{C}$ (Table 4 ) broke down completely to form wollastonite and albite. This absence of marialite at $1000^{\circ} \mathrm{C}$ is consistent with the experimental results of Rebbert (1995), who suggested that marialite is not stable at temperatures above $\sim 900^{\circ} \mathrm{C}$ (see also Pan 1998). Moreover, the angular morphologies of the prismatic grains of sodalite from all four experiments and the marialite grains from the $800^{\circ} \mathrm{C}$ runs suggest that dissolution and reprecipitation were negligible in these experiments.

The grains of sodalite and marialite from these experiments contain a thin $\mathrm{Br}$-rich rim $(\sim 1$ to $\sim 6 \mu \mathrm{m}$ wide $)$ around the original (unaffected and $\mathrm{Br}$-poor) cores (Fig. 2). With the exception of grains that have welldeveloped fractures or cleavages, the Br-rich rim on both sodalite (Fig. 2) and marialite is essentially uniform in width. The concentration profiles of $\mathrm{Br}$ across these Br-rich rims and the unaffected cores (e.g., Fig. 3) have been obtained by EMPA traverses. Note that the $\mathrm{Br}$-rich rims on marialite and sodalite from the $800^{\circ} \mathrm{C}$ experiments are less than $2 \mu \mathrm{m}$ wide. Therefore, the $\mathrm{Br}$ profiles across these rims (Fig. 3b) are constructed from average of six EMPA traverses.

The $\mathrm{Br}$ concentration profiles of marialite and sodalite (Fig. 3) have been fitted to a non-steady-state diffusion equation for constant concentrations of $\mathrm{Br}$ at the surface:
TABLE 3b. COMPOSITIONS OF SCAPOLITE-GROUP MINERALS FROM THE NICKEL PLATE Au SKARN DEPOSIT, BRITISH COLUMBIA

\begin{tabular}{|c|c|c|c|c|c|}
\hline & $401-9$ & $401-12$ & $263-12$ & $73-1-8$ & HD55 \\
\hline $\begin{array}{l}\mathrm{SiO}_{2} \mathrm{wt}^{*} \% \\
\mathrm{Al}_{2} \mathrm{O}_{3} \\
\mathrm{FeO} \\
\mathrm{CaO} \\
\mathrm{SrO} \\
\mathrm{Na}_{2} \mathrm{O} \\
\mathrm{K}_{2} \mathrm{O} \\
\mathrm{Cl} \\
\mathrm{SO}_{3} \\
\mathrm{CO}_{2}{ }^{4}\end{array}$ & $\begin{array}{c}52.6(1) \\
23.8(1) \\
0.15(2) \\
11.6(1) \\
0.07(1) \\
6.68(8) \\
0.82(4) \\
1.99(9) \\
0.02(2) \\
2.46\end{array}$ & $\begin{array}{c}52.4(4) \\
24.0(1) \\
0.18(3) \\
11.6(2) \\
0.04(1) \\
6.63(2) \\
0.78(3) \\
1.94(3) \\
0.02(1) \\
2.53\end{array}$ & $\begin{array}{c}50.8(2) \\
26.0(1) \\
0.15(1) \\
12.1(2) \\
0.01(1) \\
6.2(1) \\
1.14(2) \\
1.73(4) \\
0.00(1) \\
2.80\end{array}$ & $\begin{array}{l}53.5(2) \\
24.5(1) \\
0.06(1) \\
9.6(1) \\
0.04(1) \\
8.20(4) \\
0.85(4) \\
2.55(6) \\
0.02(1) \\
1.85\end{array}$ & $\begin{array}{c}50.4(5) \\
24.9(3) \\
0.08(1) \\
12.8(6) \\
0.06(1) \\
5.8(4) \\
0.84(9) \\
1.7(2) \\
0.02(2) \\
2.79\end{array}$ \\
\hline$-\mathrm{O}=\mathrm{Cl}$ & 0.45 & 0.44 & 0.39 & 0.58 & 0.38 \\
\hline Total & 99.7 & 99.7 & 100.6 & 100.6 & 99.0 \\
\hline $\begin{array}{l}\mathrm{Si} p f u \\
\mathrm{Al} \\
\mathrm{Fe} \\
\mathrm{Ca} \\
\mathrm{Sr} \\
\mathrm{Na} \\
\mathrm{K} \\
\mathrm{Cl} \\
\mathrm{SO}_{3} \\
\mathrm{CO}_{2}\end{array}$ & $\begin{array}{l}7.828 \\
4.172 \\
0.019 \\
1.852 \\
0.006 \\
1.927 \\
0.156 \\
0.501 \\
0.002 \\
0.497\end{array}$ & $\begin{array}{l}7.636 \\
4.362 \\
0.022 \\
1.917 \\
0.004 \\
1.905 \\
0.148 \\
0.486 \\
0.002 \\
0.512\end{array}$ & $\begin{array}{l}7.524 \\
4.533 \\
0.019 \\
1.927 \\
0.001 \\
1.779 \\
0.215 \\
0.434 \\
0.000 \\
0.566\end{array}$ & $\begin{array}{l}7.799 \\
4.213 \\
0.000 \\
1.503 \\
0.000 \\
2.318 \\
0.158 \\
0.630 \\
0.002 \\
0.368\end{array}$ & \begin{tabular}{l|}
7.586 \\
4.414 \\
0.001 \\
2.068 \\
0.005 \\
1.682 \\
0.161 \\
0.425 \\
0.002 \\
0.573
\end{tabular} \\
\hline Me & 47 & 45 & 51 & 40 & 53 \\
\hline $\mathrm{Br} \mathrm{ppm}$ & $114(6)$ & $108(7)$ & $31(4)$ & $45(3)$ & $128(9)$ \\
\hline
\end{tabular}

* total iron as $\mathrm{FeO} ;{ }^{\dagger}$ calculated on the basis of stoichiometry;
$\mathrm{Me}: 100(\mathrm{Ca}+\mathrm{Sr}) /(\mathrm{Ca}+\mathrm{Sr}+\mathrm{Na}+\mathrm{K}) ; p f u$ : proportion of atom or group per formula $M e: 100(\mathrm{Ca}+\mathrm{Sr}) /(\mathrm{Ca}+\mathrm{Sr}+\mathrm{Na}+\mathrm{K}) ; p f u$ : proportion of atom or $\mathrm{g}, \mathrm{uu}$
unit. Numbers in parentheses are standard deviations (one sigma) 
TABLE 3c. COMPOSITIONS OF SCAPOLITE-GROUP MINERALS FROM THE GRENVILLE U-Th-Mo-REE DEPOSITS, ONTARIO AND QUEBEC

DL-22B DL-26A DL-28A DL-45D DL-60A DL-60G DL-61A DL-62C DL-66H DL-70N DL-70K DL70K $^{\mathrm{b}}$

\begin{tabular}{|c|c|c|c|c|c|c|c|c|c|c|c|c|}
\hline $\mathrm{SiO}_{2} \mathrm{wt} \%$ & $52.7(5)$ & $50.7(2)$ & $51.1(4)$ & $58.4(4)$ & $52.4(5)$ & $53.5(3)$ & $43.2(9)$ & $50.6(6)$ & $54.7(4)$ & $47.9(5)$ & $49.9(3)$ & 52.(1) \\
\hline $\mathrm{Al}_{2} \mathrm{O}_{3}$ & $24.4(2)$ & $25.0(2)$ & $24.9(5)$ & $22.4(1)$ & $24.2(3)$ & 24.11) & $29.3(5)$ & $25.1(2)$ & $23.2(2)$ & $26.1(5)$ & $25.4(1)$ & $24.4(1)$ \\
\hline $\mathrm{FeO}^{*}$ & $0.09(4)$ & $0.05(2)$ & $0.06(3)$ & $0.01(1)$ & $0.08(2)$ & $0.09(2)$ & $0.02(1)$ & $0.03(1)$ & $0.13(3)$ & $0.04(3)$ & $0.06(2)$ & $0.06(1)$ \\
\hline $\mathrm{CaO}$ & $11.1(3)$ & $12.9(1)$ & $12.0(3)$ & $6.9(4)$ & $11.3(5)$ & $10.6(1)$ & $19.1(3)$ & $12.7(4)$ & $8.73(8)$ & $14.9(4)$ & $13.7(1)$ & $10.8(9)$ \\
\hline $\mathrm{SrO}$ & $0.12(2)$ & $0.16(2)$ & $0.16(4)$ & $0.03(3)$ & $0.25(2)$ & $0.26(2)$ & $0.39(3)$ & $0.29(4)$ & $0.22(4)$ & $0.24(6)$ & $0.19(2)$ & $0.25(1)$ \\
\hline $\mathrm{Na}_{2} \mathrm{O}$ & $6.9(1)$ & $6.0(1)$ & $6.3(2)$ & $8.7(4)$ & $6.7(3)$ & $6.9(2)$ & $2.4(2)$ & $6.0(3)$ & $7.9(1)$ & $4.7(3)$ & $5.44(9)$ & $7.1(8)$ \\
\hline $\mathrm{K}_{2} \mathrm{O}$ & $1.08(9)$ & $0.44(4)$ & $0.94(5)$ & $1.0(1)$ & $1.01)$ & $0.98(6)$ & $0.07(3)$ & $0.58(6)$ & $1.01(8)$ & $0.70(5)$ & $0.56(6)$ & $0.82(2)$ \\
\hline $\mathrm{Cl}$ & $2.06(8)$ & $1.19(3)$ & $1.7(1)$ & $3.3(1)$ & $1.8(1)$ & $1.97(5)$ & $0.20(3)$ & $1.5(1)$ & $2.45(3)$ & $1.0(1)$ & $1.24(6)$ & $2.0(4)$ \\
\hline $\mathrm{SO}_{3}$ & $0.18(4)$ & $1.51(7)$ & $1.2(1)$ & $0.01(2)$ & 1.11) & $1.10(1)$ & $1.8(1)$ & $1.1(1)$ & $0.53(8)$ & $1.68(4)$ & $1.6(1)$ & $1.0(3)$ \\
\hline $\mathrm{CO}_{2}$ & 2.32 & 2.56 & 2.19 & 1.20 & 2.09 & 1.95 & 3.51 & 2.41 & 1.68 & 2.63 & 2.46 & 1.88 \\
\hline$-\mathrm{O}=\mathrm{Cl}$ & 0.46 & 0.27 & 0.38 & 0.73 & 0.41 & 0.44 & 0.05 & 0.34 & 0.55 & 0.23 & 0.28 & 0.46 \\
\hline Total & 100.5 & 99.8 & 100.2 & 101.3 & 100.5 & 101.1 & 99.9 & 100.0 & 100.0 & 99.6 & 100.3 & 100.5 \\
\hline Si $p f u$ & 7.763 & 7.630 & 7.623 & 8.265 & 7.765 & 7.837 & 6.663 & 7.579 & 8.000 & 7.312 & 7.503 & 7.751 \\
\hline $\mathrm{Al}$ & 4.237 & 4.370 & 4.377 & 3.735 & 4.235 & 4.163 & 5.337 & 4.421 & 4.000 & 4.688 & 4.497 & 4.249 \\
\hline $\mathrm{Fe}$ & 0.002 & 0.001 & 0.002 & 0.001 & 0.008 & 0.010 & 0.003 & 0.004 & 0.014 & 0.003 & 0.007 & 0.007 \\
\hline $\mathrm{Ca}$ & 1.748 & 2.075 & 1.918 & 1.043 & 1.794 & 1.669 & 3.154 & 2.039 & 1.368 & 2. & 2.201 & 1.710 \\
\hline $\mathrm{Sr}$ & 0.011 & 0.014 & 0.013 & 0.002 & 0.019 & 0.022 & 0.035 & 0.025 & 0.018 & 0.021 & 0.017 & 0.022 \\
\hline $\mathrm{Na}$ & 1.963 & 1.751 & 1.824 & 2.391 & 2.001 & 1.946 & 0.719 & 1.741 & 2.244 & 1.385 & 1.586 & 2.020 \\
\hline $\mathrm{K}$ & 0.203 & 0.085 & 0.180 & 0.183 & 0.210 & 0.184 & 0.014 & 0.111 & 0.189 & 0.137 & 0.118 & 0.155 \\
\hline $\mathrm{Cl}$ & 0.514 & 0.303 & 0.426 & 0.767 & 0.459 & 0.488 & 0.053 & 0.381 & 0.6 & 0.259 & 0.317 & 0.507 \\
\hline $\mathrm{SO}_{3}$ & 0.020 & 0.171 & 0.128 & 0.001 & 0.119 & 0.122 & 0.207 & 0.126 & 0.058 & 0.137 & 0.178 & 0.115 \\
\hline $\mathrm{CO}_{2}$ & 0.466 & 0.526 & 0.446 & 0.232 & 0.423 & 0.390 & 0.740 & 0.493 & 0.335 & 0.549 & 0.505 & 0.378 \\
\hline Me & 45 & 53 & 49 & 29 & 45 & 44 & 81 & 52 & 36 & 62 & 56 & 44 \\
\hline $\mathrm{Br} \mathrm{ppm}$ & $108(11)$ & $1(3) \quad 144$ & (15) 10 & 3) & $8(2)$ & (5) & (5) & 3) & (5) & (1) & $(5)$ & 14) \\
\hline
\end{tabular}

* total iron as $\mathrm{FeO} ; \uparrow$ calculated on the basis of stoichiometry; $M e=100(\mathrm{Ca}+\mathrm{Sr}) /(\mathrm{Ca}+\mathrm{Sr}+\mathrm{Na}+\mathrm{K})$; a and $\mathrm{b}$, two populations of DL-70K; numbers in parentheses are standard deviations (one sigma).

TABLE 4. SUMMARY OF EXCHANGE EXPERIMENTS

\begin{tabular}{lccccccc}
\hline Run \# & $\begin{array}{c}\mathrm{NaCl} / \\
\mathrm{NaBr}\end{array}$ & $\begin{array}{c}\mathrm{T} \\
{ }^{\circ} \mathrm{C}\end{array}$ & $\begin{array}{c}\text { Time } \\
\mathrm{s}\end{array}$ & $\mathrm{Cl} / \mathrm{Br}^{\dagger}$ & $K_{\mathrm{D}}$ & $\begin{array}{c}\mathrm{D} \\
\mathrm{m}^{2} / \mathrm{s}\end{array}$ & $\begin{array}{c}\mathrm{Log} \\
\mathrm{D}\end{array}$ \\
\hline $\mathrm{SCP}-1-1$ & $1: 1$ & 800 & $2.59 \times 10^{6}$ & $0.8 \pm 0.1$ & $1.1 \pm 0.1$ & $1.98 \times 10^{-19}$ & -18.70 \\
$\mathrm{SCP}-1-2$ & $2: 1$ & 800 & $2.59 \times 10^{6}$ & $1.8 \pm 0.1$ & $1.1 \pm 0.1$ & $1.48 \times 10^{-19}$ & -18.83 \\
$\mathrm{SCP}-1-3$ & $1: 1$ & 1000 & $1.05 \times 10^{6}$ & & & & \\
$\mathrm{SCP}-1-4$ & $2: 1$ & 1000 & $1.05 \times 10^{6}$ & & & & \\
& & & & & & & \\
SOD-3-1 & $1: 1$ & 800 & $2.59 \times 10^{6}$ & $0.6 \pm 0.1$ & $0.85 \pm 0.09$ & $8.13 \times 10^{-20}$ & -19.09 \\
SOD-3-2 & $2: 1$ & 800 & $2.59 \times 10^{6}$ & $1.4 \pm 0.1$ & $0.9 \pm 0.1$ & $4.13 \times 10^{-20}$ & -19.38 \\
SOD-3-3 & $1: 1$ & 1000 & $1.05 \times 10^{6}$ & $0.6 \pm 0.1$ & $0.75 \pm 0.09$ & $8.68 \times 10^{-18}$ & -17.06 \\
SOD-3-4 & $2: 1$ & 1000 & $1.05 \times 10^{6}$ & $1.5 \pm 0.1$ & $1.0 \pm 0.2$ & $4.79 \times 10^{-18}$ & -17.32 \\
& & & & & & & \\
\hline
\end{tabular}

the surface $\mathrm{Cl} / \mathrm{Br}$ values (i.e., weight ratios) of marialite and sodalite are based on $\mathrm{Cl}$ and $\mathrm{Br}$ contents extrapolated from the EMPA traverses (see text for explanation)

$$
\mathrm{C}_{\mathrm{x}, \mathrm{t}}=\mathrm{C}_{0}\left[1-\operatorname{erf}\left(\frac{\mathrm{x}}{2 \sqrt{\mathrm{Dt}}}\right)\right]
$$

where $\mathrm{C}_{\mathrm{x}, \mathrm{t}}$ is the concentration of $\mathrm{Br}$ at depth $\mathrm{x}$ and time $\mathrm{t}$ from the surface, $\mathrm{C}_{0}$ is the surface concentration of $\mathrm{Br}$, and $\mathrm{D}$ is the diffusion coefficient in $\mathrm{m}^{2} / \mathrm{s}$ (Crank 1975). Here, the surface $\mathrm{Cl} / \mathrm{Br}$ values of marialite and sodalite cannot be determined directly by EMPA owing to un-

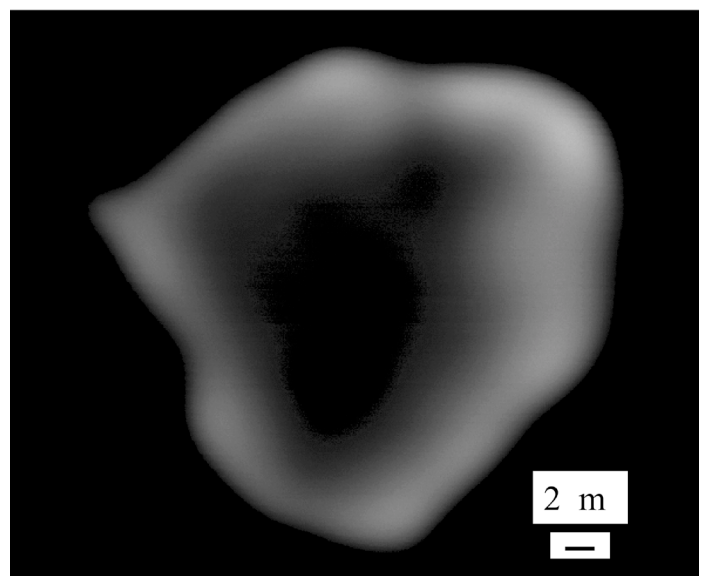

FIG. 2. Back-scattered electron image illustrating a Br-rich rim around the original (Br-poor) core of a sodalite grain from experiment SOD-3-1. Note that the width of the Brrich rim is fairly uniform. 
avoidable edge-effects (e.g., interference from melts and epoxy resin), and hence are extrapolated from the concentration profiles (Fig. 3).

The estimated diffusion-coefficients of $\mathrm{Br}$ in sodalite and marialite are given in Table 4 . The Br diffusivity in these minerals appears to have a compositional dependence, i.e., increase in $\mathrm{D}$ with increasing surface concentrations of $\mathrm{Br}$ at a given temperature (Table 4). Also, the $\mathrm{D}$ values of $\mathrm{Br}$ in marialite and sodalite at $800^{\circ} \mathrm{C}$ are similar. A least-squares fit to the data from the sodalite experiments (Table 4, Fig. 4) yields an Arrhenius relation: $\mathrm{D}=6.5 \times 10^{-7} \exp (-270 \pm 10 \mathrm{~kJ} / \mathrm{mol} / \mathrm{RT}) \mathrm{m}^{2} / \mathrm{s}$, over the temperature range from 800 to $1000^{\circ} \mathrm{C}$.

Figure 4 shows that the diffusion rates of $\mathrm{Br}$ in marialite and sodalite are significantly lower than those of $\mathrm{F}-\mathrm{Cl}-\mathrm{OH}$ along the $c$ axis, broadly similar to those of $\mathrm{F}-\mathrm{Cl}-\mathrm{OH}$ parallel to the $a$ axis and of $\mathrm{Sr}$, but are much lower than those of $\mathrm{Nd}$ (and other rare-earth elements) in the apatite-group minerals (Brenan 1993, Cherniak \& Ryerson 1993, Cherniak 2000). The rapid diffusion of $\mathrm{F}-\mathrm{Cl}-\mathrm{OH}$ along the $c$-axis direction in apatite-group minerals has been attributed to the location of these anions in the $c$-axis channels (Brenan 1993). The $\mathrm{Cl}^{-}$ and $\mathrm{Br}^{-}$ions in scapolite-group minerals and sodalite are located in large cages surrounded by rings of $(\mathrm{Al}, \mathrm{Si})$ tetrahedra (Papike \& Zoltai 1965, Fleet 1989) and, unlike $\mathrm{F}-\mathrm{Cl}-\mathrm{OH}$ in apatite-group minerals, are not con-

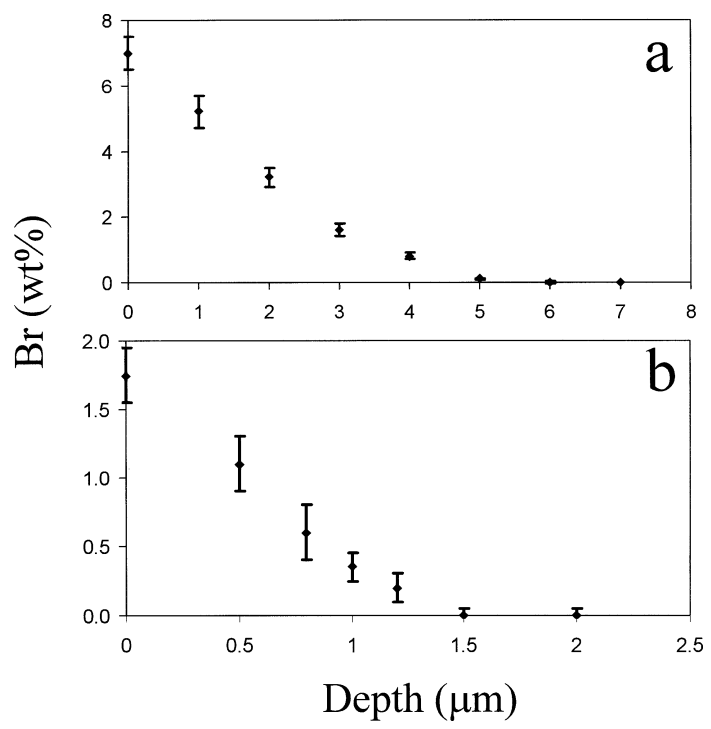

FIG. 3. Representative $\mathrm{Br}$ profiles across the rims of: a) marialite of experiment SCP-1-1 (average of spot analyses from six different traverses), and b) sodalite of experiment SOD-3-1. Note that the $\mathrm{Br}$ contents at the surface $($ depth $=0)$ of mineral grains cannot be determined by EMPA, but are extrapolated from individual traverses. fined to channels. Also, the $\mathrm{Br}^{-}$ion $(1.96 \AA)$ is significantly larger than $\mathrm{F}^{-}, \mathrm{OH}^{-}$and $\mathrm{Cl}^{-}(1.33,1.37$ and 1.81 $\AA$ A, respectively; Shannon 1976). These differences are most likely responsible for the considerably slower diffusivities of $\mathrm{Br}$ in scapolite-group minerals and sodalite than those of $\mathrm{F}-\mathrm{Cl}-\mathrm{OH}$ parallel to the $c$ axis in apatite-group minerals.

The relatively rapid rates of diffusion of $\mathrm{F}-\mathrm{Cl}-\mathrm{OH}$ in apatite-group minerals led Brenan (1993) to express caution about the application of the halogen chemistry of these minerals to infer melt/fluid compositions, because of possible modification during subsequent thermal events. Dobson (1973) formulated the closure temperatures $\left(\mathrm{T}_{\mathrm{c}}\right)$ of slowly diffusing species in mineral grains as follows:

$$
\mathrm{T}_{\mathrm{C}}=\frac{\mathrm{E}_{\mathrm{a}} / \mathrm{R}}{\ln \left(\frac{\mathrm{ART}_{\mathrm{c}}^{2} \mathrm{D}_{\mathrm{o}} / \mathrm{a}^{2}}{\mathrm{E}_{\mathrm{a}} \mathrm{dT} / \mathrm{dt}}\right)}
$$

where $E_{a}$ is the activation energy of diffusion, $R$ is the gas constant, $D_{0}$ is the pre-exponential term, $A$ is a geometric factor, a is the grain radius, and dT/dt is the cooling rate. Ganguly \& Tirone (1999) pointed out that Dobson's (1973) formulation is applicable only to minerals that have undergone large extents of diffusion (i.e., even the composition at the core of individual grains is affected). Figure 5 shows that the closure temperatures

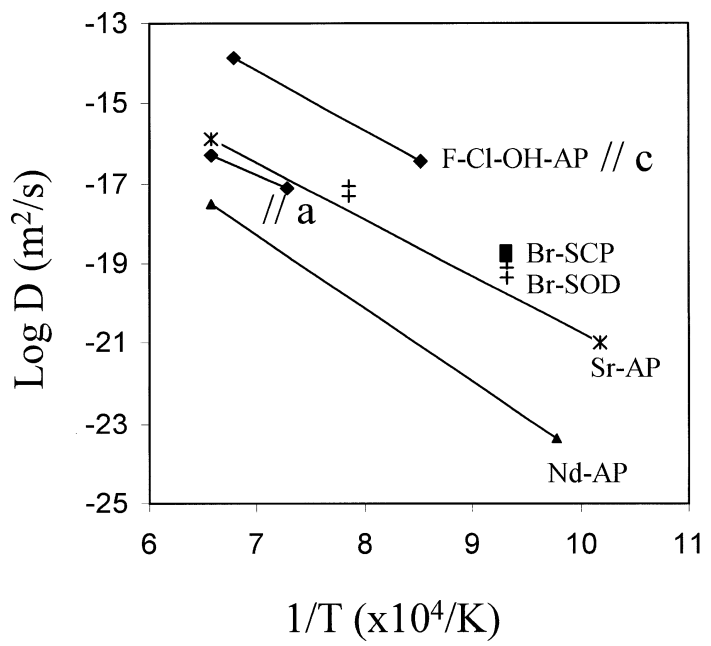

FIG. 4. Arrhenius plot illustrating Br diffusivities in marialite and sodalite. Also shown for comparison are the diffusivities of $\mathrm{F}-\mathrm{Cl}-\mathrm{OH}$ (// $c$ and $/ / a$ at 1 atmosphere), $\mathrm{Sr}$ and $\mathrm{Nd}$ in apatite-group minerals (data from Brenan 1993, Cherniak \& Ryerson 1993, Cherniak 2000). 
of $\mathrm{Br}$ in sodalite are significantly higher than those of $\mathrm{F}-\mathrm{Cl}-\mathrm{OH}$ in apatite-group minerals, but are close to those of $\mathrm{Sr}$ in apatite-group minerals. The closure temperatures of $\mathrm{Br}$ in marialite are probably similar to those of this element in sodalite, because of similarities in the experimentally determined $\mathrm{D}_{\mathrm{Br}}$ at $800^{\circ} \mathrm{C}$ (Table 4) and the structural environments of $\mathrm{Br}$ in these minerals.

$\mathrm{The} \mathrm{Br}-\mathrm{Cl}$ exchange between marialite or sodalite and hydrous halide melts can be represented by the following reaction:

$$
\mathrm{Br}_{\text {mineral }}^{-}+\mathrm{Cl}^{-} \text {melt }=\mathrm{Br}_{\text {melt }}^{-}+\mathrm{Cl}_{\text {mineral }}^{-}
$$

The expression for the distribution coefficient of this exchange equilibrium is:

$$
\mathrm{K}_{\mathrm{D}}{ }^{\text {mineral-melt }}=\left(X_{\mathrm{Cl}} / \mathrm{X}_{\mathrm{Br}}\right)^{\text {mineral }} /\left(\mathrm{X}_{\mathrm{Br}} / \mathrm{X}_{\mathrm{Cl}}\right)^{\text {melt }} \text {. }
$$

The $\mathrm{Cl} / \mathrm{Br}$ values of the ion-exchanged sodalite at the surface (Fig. 3) are marginally lower than those of the starting materials, giving $\mathrm{K}_{\mathrm{D}}$ sodalite-melt from $0.75 \pm 0.09$ to $1.0 \pm 0.1$ (Table 4 ; average $0.9 \pm 0.1$ ). The $\mathrm{Cl} / \mathrm{Br}$ values of the ion-exchanged marialite at the surface are similar to those in the starting materials, yielding $\mathrm{K}_{\mathrm{D}}{ }^{\text {marialite-melt }}$ close to unity (Table 4 ; average $0.97 \pm$ 0.08 ). There is no significant difference in the estimated $\mathrm{K}_{\mathrm{D}}{ }^{\text {sodalite-melt }}$ values from experiments at 800 and $1000^{\circ} \mathrm{C}$ (Table 4).

These $\mathrm{K}_{\mathrm{D}}{ }^{\text {mineral-melt }}$ values for marialite and sodalite, resulting in no significant $\mathrm{Cl} / \mathrm{Br}$ fractionation, are distinct from those for halides (Stoessell \& Carpenter 1986, Berndt \& Seyfried 1997, Siemann \& Schramm 2002) and apatite-group minerals (Dong \& Pan 2002), all of which have marked preference for $\mathrm{Cl}$ over $\mathrm{Br}$. This approximately equal uptake of $\mathrm{Cl}$ and $\mathrm{Br}$ by scapolite-

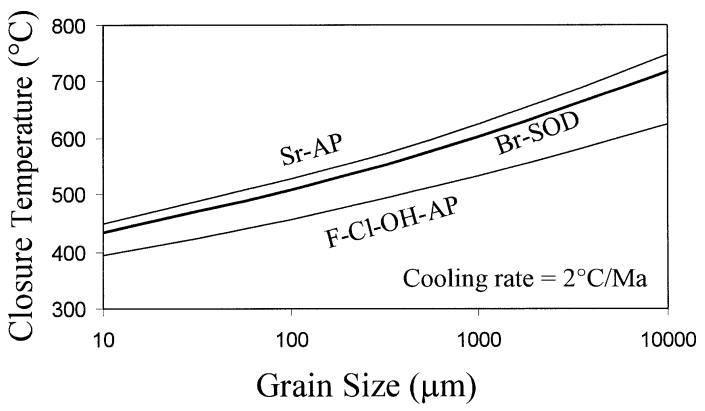

FIG. 5. Closure temperatures for $\mathrm{Br}$ in sodalite (Br-SOD, heavy line) as a function of grain sizes at an assumed cooling rate of $2^{\circ} \mathrm{C} / \mathrm{Ma}$ and a spherical geometry, using the formulation of Dobson (1973). Also shown for comparison are values for $\mathrm{F}-\mathrm{Cl}-\mathrm{OH}$ and $\mathrm{Sr}$ in grains of apatite-group minerals ( $\mathrm{F}-\mathrm{Cl}-\mathrm{OH}-\mathrm{AP}$ and $\mathrm{Sr}-\mathrm{AP}$, light lines) under similar assumptions (diffusivity data from Brenan 1993, Cherniak \& Ryerson 1993). group minerals and sodalite is probably attributable to their accommodation in the large structural cages of these framework aluminosilicates (Papike \& Zoltai 1965, Fleet 1989). Fleet (1989) successfully synthesized $\mathrm{Na}_{8}\left(\mathrm{Al}_{6} \mathrm{Ge}_{6}\right) \mathrm{O}_{24} \mathrm{Cl}_{2}, \mathrm{Na}_{8}\left(\mathrm{Al}_{6} \mathrm{Ge}_{6}\right) \mathrm{O}_{24} \mathrm{Br}_{2}$ and $\mathrm{Na}_{8}\left(\mathrm{Al}_{6}\right.$ $\left.\mathrm{Ge}_{6}\right) \mathrm{O}_{24} \mathrm{I}_{2}$, with the still larger $\mathrm{I}^{-}$ion $(2.20 \AA$ : Shannon 1976) accommodated in the cage of sodium aluminogermanate sodalite.

\section{Application to scapolite-group minerals in skarn deposits}

Results of combined EMPA and XRF microprobe analyses of scapolite-group minerals from the Tieshan, Nickel Plate and Grenville deposits (Tables 3a, b, c) are illustrated in Figure 6. Levels of major and minor elements (e.g., $\mathrm{Fe}, \mathrm{Sr}$ and $\mathrm{K}$ ) in these samples of scapolitegroup minerals are within the ranges in the literature (e.g., Shaw 1960, Teertstra \& Sherriff 1997). All samples from the Tieshan deposit are marialite $\left(\mathrm{Me}_{23}\right.$ to $M e_{44}$ ), whereas those from the Nickel Plate and Grenville deposits vary from marialite to meonite (Tables 3a, b, c, Fig. 6).

Bromine in scapolite-group minerals of these skarn deposits varies widely, from $25 \mathrm{ppm}$ in a sample of meionite $\left(M e_{81}\right)$ to $144 \mathrm{ppm}$ in marialite $\left(\mathrm{Me}_{49}\right.$; Tables $3 \mathrm{a}, \mathrm{b}, \mathrm{c})$. The relatively small standard deviations of most samples indicate that $\mathrm{Br}$ in scapolite-group minerals is homogeneous in its distribution. However, marialite from sample DL-70K has two populations of different $\mathrm{Br}$ and $\mathrm{Cl}$ contents (Table 3c). It is noteworthy that their $\mathrm{Cl} / \mathrm{Br}$ values are similar (Fig. 7), and that the $\mathrm{Cl}$ and $\mathrm{Br}$ contents both vary with the $\mathrm{Al} / \mathrm{Si}$ and $\mathrm{Na} / \mathrm{Ca}$ values, indicative of a crystal-chemical control (Pan et al. 1994).

The $\mathrm{Cl} / \mathrm{Br}$ values of marialite (weight ratio) from the Tieshan deposit cluster around $650 \pm 40$ (Fig. 7a), whereas those of scapolite-group minerals from the Nickel Plate and Grenville deposits are more variable (Tables $3 \mathrm{~b}, \mathrm{c}$ ). In particular, the $\mathrm{Cl} / \mathrm{Br}$ values of scapolite-group minerals in the Nickel Plate deposit increase from endoskarn (170 to 180 ) to exoskarn (560 to 570 ;

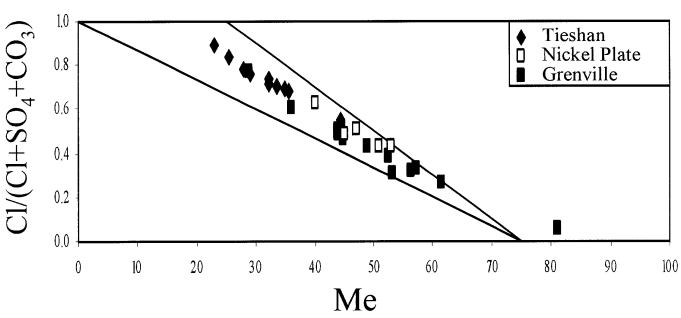

FIG. 6. $X(\mathrm{Cl})$ versus Me plot illustrating the compositions of scapolite-group minerals from the Tieshan, Nickel Plate and Grenville deposits. $M e$ : meionite content. 
Table $3 \mathrm{~b}$ ), whereas in the marialite crystals lining cavities in the Copperfield breccia, the $\mathrm{Cl} / \mathrm{Br}$ value is 130 (Fig. 7a). Scapolite-group minerals in the Grenville deposits reveal a range of $\mathrm{Cl} / \mathrm{Br}$ values from 80 to 380 (Table 3c, Fig. 7b).

Our exchange experiments have shown that the $\mathrm{Cl} /$ $\mathrm{Br}$ values in scapolite-group minerals closely reflect those of its coexisting melts or fluids. Therefore, the $\mathrm{Cl} /$ $\mathrm{Br}$ values of scapolite-group minerals from the skarn deposits are useful in providing constraints on the compositions and sources of ore-forming fluids. For example, the $\mathrm{Cl} / \mathrm{Br}$ values of marialite in the Tieshan deposit are considerably higher than that of seawater ( 280; You et al. 1994), but can be explained by the dissolution of halite and sylvite as a mode of origin of the hydrothermal brines (Fig. 7a), providing further support for a genetic model of this deposit involving marine evaporites as country rocks (Pan \& Dong 1999). Also, the $\mathrm{Cl} / \mathrm{Br}$ values of scapolite-group minerals in the exoskarns of the Nickel Plate deposit are close to those of the Tieshan deposit, and may indicate a similar origin. The increase in $\mathrm{Cl} / \mathrm{Br}$ from endoskarn to exoskarn is readily attributable to an increased involvement of magmatic $\mathrm{H}_{2} \mathrm{O}$ in the former. Similarly, the wide variation in $\mathrm{Cl} / \mathrm{Br}$ in scapolite-group minerals from the Grenville deposits (Fig. 7b) is consistent with varying degrees of mixing of hydrothermal fluids derived

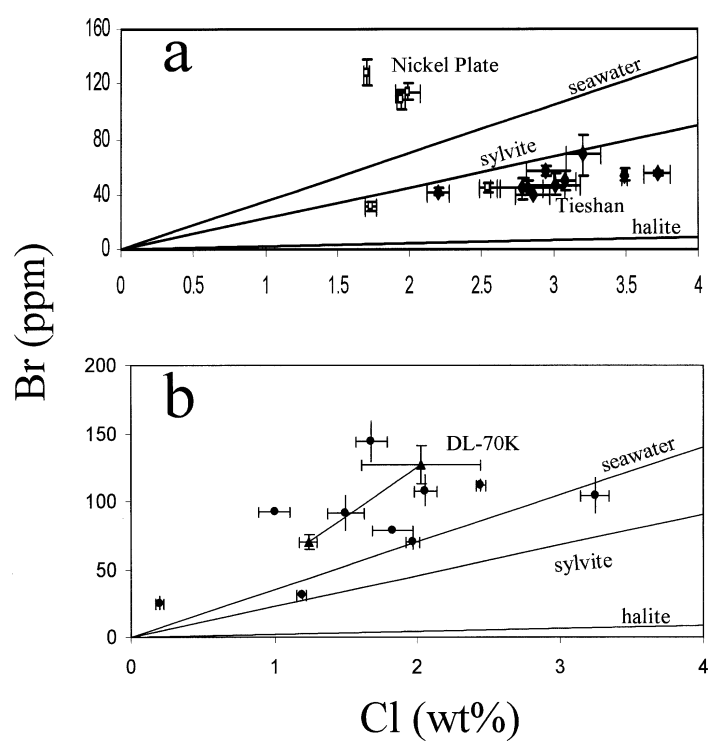

FIG. 7. $\mathrm{Br}(\mathrm{ppm})$ versus $\mathrm{Cl}(\mathrm{wt} \%$ ) plots illustrating scapolitegroup minerals from: a) the Tieshan and Nickel Plate skarn deposits, and b) the Grenville pegmatite, skarn, and vein deposits. The reference lines represent the $\mathrm{Cl} / \mathrm{Br}$ values of seawater, halite and sylvite (data from Stoessell \& Carpenter 1986, You et al. 1994, Siemann \& Schramm 2002). from magmatic sources and associated sedimentary rocks (Lentz 1992, 1998).

Finally, there have been numerous applications of $\mathrm{Cl} / \mathrm{Br}$ systematics from fluid inclusions in constraining the sources and evolution of hydrothermal fluids in a variety of mineral deposits (e.g., Kesler et al. 1995). In the present study, we show that the $\mathrm{Cl} / \mathrm{Br}$ values in $\mathrm{Cl}$ rich minerals are also useful tracers for the compositions and sources of ore-forming fluids, provided that the distribution coefficients of $\mathrm{Cl}$ and $\mathrm{Br}$ between minerals and coexisting melts and fluids are known. In this respect, scapolite-group minerals and sodalite are special cases in that their $\mathrm{Cl} / \mathrm{Br}$ values can be used directly as tracers for the sources and evolution of hydrothermal fluids, because their $K_{D}$ values are close to unity. Another advantage of scapolite-group minerals and sodalite is that the $\mathrm{Cl} / \mathrm{Br}$ values in these minerals from skarn systems and medium-grade metamorphic terranes are not significantly affected during cooling processes (Fig. 5), unlike those in fluid inclusions.

\section{ACKNOWLEDGEMENTS}

We thank C.M. Clark, D.R. Lentz, R.F. Martin, E. Sokolova and an unnamed referee for constructive criticism and many helpful suggestions. We also thank the Saskatchewan Ministry of Economic Development for providing a Strategic Initiative Fund grant for the purchase of the XRF microprobe, A. Cheburkin of the EMMA Analytical Inc. for installation of the XRF microprobe, M.E. Fleet for provision of synthetic $\mathrm{Na}_{8}\left(\mathrm{Al}_{6} \mathrm{Ge}_{6}\right) \mathrm{O}_{24} \mathrm{Br}_{2}$ crystals and for advice on the crystal structure of sodalite, and D.R. Lentz for provision of samples from the Grenville deposits. Additional financial support for this study was provided by an NSERC research grant.

\section{REFERENCES}

ApPEL, P.W.U. (1997): High bromine contents and low Cl/Br ratios in hydrothermally altered Archean komatiitic rocks, West Greenland. Precamb. Res. 82, 177-189.

Berndt, M.E. \& SEyfried, W.E., JR. (1997): Calibration of $\mathrm{Br} / \mathrm{Cl}$ fractionation during phase separation of seawater: possible halite at $9^{\circ}$ to $10^{\circ} \mathrm{N}$ East Pacific Rise. Geochim. Cosmochim. Acta 61, 2849-2854.

BÖHLKE, J.K. \& IRWIN, J.J. (1992): Laser microprobe analysis of $\mathrm{Cl}, \mathrm{Br}$, I, and $\mathrm{K}$ in fluid inclusions: implications for sources of salinity in some ancient hydrothermal fluids. Geochim. Cosmochim. Acta 56, 203-225.

Boness, M., Heumann, K.G. \& HaAck, U. (1991): Cl, Br and I analyses of metamorphic and sedimentary rocks by isotope dilution mass spectrometry. Contrib. Mineral. Petrol. 107, 94-99.

BREnAN, J. (1993): Kinetics of fluorine, chlorine and hydroxyl exchange in fluorapatite. Chem. Geol. 110, 195-210. 
CArroll, M.R. \& WeBster, J.D. (1994): Solubilities of sulfur, noble gases, nitrogen, chlorine and fluorine in magmas. Rev. Mineral. 30, 231-279.

Channer, D.M.DeR., De Ronde, C.E.J. \& Spooner, E.T.C. (1997). The $\mathrm{Cl}^{-}-\mathrm{Br}^{-}-\mathrm{I}^{-}$composition of $~ 3.23 \mathrm{Ga}$ modified seawater: implications for the geological evolution of ocean halide chemistry. Earth Planet. Sci. Lett. 150, 325-335.

Cheburkin, A.K. Frei, R. \& Shotyk, W. (1997): An energydispersive miniprobe multielement analyzer (EMMA) for direct analysis of trace elements and chemical age dating in single mineral grains. Chem. Geol. 135, 75-87.

CHERNIAK, D.J. (2000): Rare earth element diffusion in apatite. Geochim. Cosmochim. Acta 64, 3871-3885.

\& RYERSON, F.J. (1993): A study of strontium diffusion in apatite using Rutherford backscattering spectroscopy and ion implantation. Geochim. Cosmochim. Acta 57, 4653-4666.

CRANK, J. (1975): The Mathematics of Diffusion (2 $2^{\text {nd }}$ ed.). Oxford University Press, London, U.K.

Dobson, M.H. (1973): Closure temperature in cooling geochronological and petrological systems. Contrib. Mineral. Petrol. 40, 259-274.

Dong, PING \& PAN, YuANMING (2002): F-Cl-Br partitioning between apatites and halide-rich melts: experimental studies and applications. Geol. Assoc. Can. - Mineral. Assoc. Can., Program. Abstr. 27, A29.

FLEET, M.E. (1989): Structures of sodium alumino-germanates sodalites $\left[\mathrm{Na}_{8}\left(\mathrm{Al}_{6} \mathrm{Ge}_{6} \mathrm{O}_{24}\right) \mathrm{A}_{2}, \mathrm{~A}=\mathrm{Cl}, \mathrm{Br}, \mathrm{I}\right]$. Acta Crystallogr. C45, 843-847.

Ganguly, J. \& Tirone, M. (1999): Diffusion closure temperature and age of a mineral with arbitrary extent of diffusion: theoretical formulation and applications. Earth Planet. Sci. Lett. 170, 131-140.

GOVINDARAJU, K. (1994): 1994 compilation of working values and sample description for 383 geostandards. Geostandards Newslett. 18.

Heumann, K.G., Gall, M. \& Weiss, H. (1987): Geochemical investigations to explain iodine-overabundances in Antarctic meteorites. Geochim. Cosmochim. Acta 51, 2541-2547.

Kesler, S.E., Appold, M.S., Martini, A.M., Walter, L.M., Huston, T.J. \& KYLE, J.R. (1995): Na-Cl-Br systematics of mineralizing brines in Mississippi Valley-type deposits. Geology 23, 641-644.

LENTZ, D.R. (1992): Petrogenesis of U-, Mo-, and REE-bearing pegmatites, skarns, and veins in the Central Metasedimentary Belt of the Southwestern Grenville Province, Ontario and Quebec. Ph.D. thesis, Univ. of Ottawa, Ottawa, Ontario.

(1998): Late-tectonic U-Th-Mo-REE skarn and carbonatitic vein-dyke systems in the southwestern
Grenville Province: a pegmatite-related pneumatolytic model linked to marble melting (limestone syntexis). In Mineralized Intrusion-Related Skarn Systems (D.R. Lentz, ed.). Mineral. Assoc. Can., Short Course 26, 519-567.

MARKL, G. \& PiAzolo, S. (1998): Halogen-bearing minerals in syenites and high-grade marbles of Droning Maud Land, Antarctica: monitors of fluid compositional changes during late magmatic fluid-rock interaction processes. Contrib. Mineral. Petrol. 132, 246-268.

McCAig, A.M., Tritlla, J. \& Banks, D.A. (2000): Fluid mixing and recycling during Pyrenean thrusting: evidence from fluid inclusion halogen ratios. Geochim. Cosmochim. Acta 64, 3395-3412.

O'ReILly, S.Y. \& GRIFFIN, W.L. (2000): Apatite in the mantle: implications for metasomatic processes and high heat production in Phanerozoic mantle. Lithos 53, 217-232.

Pan, Yuanming (1998): Scapolite in skarn deposits: petrogenetic and geochemical significance. In Mineralized Intrusion-Related Skarn Systems (D.R. Lentz, ed.). Mineral. Assoc. Can., Short Course 26, 169-210.

\& Dong, PING (1999): The Lower Changjiang (Yangzi/Yangtze River) metallogenic belt, East Central China: intrusion- and wallrock-hosted $\mathrm{Cu}-\mathrm{Fe}-\mathrm{Au}, \mathrm{Mo}, \mathrm{Zn}$, $\mathrm{Pb}, \mathrm{Ag}$ deposits. Ore Geol. Rev. 15, 177-244.

FLEET, M.E. \& RAY, G.E. (1994): Scapolite in two Canadian gold deposits: Nickel Plate, British Columbia and Hemlo, Ontario. Can. Mineral. 32, 825-837.

PAPIKE, J.J. \& ZoltaI, T. (1965): The crystal structure of a marialite scapolite. Am. Mineral. 50, 641-655.

RAuP, O.B. \& Hite, R.J. (1996): Bromine geochemistry of chloride rocks of the Middle Pennsylvanian Paradox Formation of the Hermosa Group, Paradox Basin, Utah and Colorado. U.S. Geol. Surv., Bull. 2000-M.

Rebbert, C.R. (1995): Studies of Volatile-Bearing Silicate Minerals: $\mathrm{Cl}-\mathrm{CO}_{3}$ Scapolite Solution Properties and Hydrothermal Oxidation of Synthetic Iron Biotite. Ph.D. thesis, Univ. Oregon, Eugene, Oregon.

SEYFried, W.E., JR., BERndT, M.E. \& JANECKy, D.R. (1986): Chloride depletions and enrichments in seafloor hydrothermal fluids: constraints from experimental basalt alteration studies. Geochim. Cosmochim. Acta 50, 469-475.

ShanNON, R.D. (1976): Revised effective ionic radii and systematic studies of interatomic distances in halides and chalcogenides. Acta Crystallogr. A32, 751-767.

SHAw, D.M. (1960): The geochemistry of scapolite. II. Trace elements, petrology, and general geochemistry. J. Petrol. 1, 261-285.

Shinonaga, T., Ebihara, M., Nakahara, H., Tomura, K. \& Heumann, K. (1994): Cl, Br and I in igneous standard rocks. Chem. Geol. 115, 213-225. 
Siemann, M.G. \& Schramm, M. (2002): Henry's and nonHenry's law behavior of $\mathrm{Br}$ in simple marine systems. Geochim. Cosmohim. Acta 66, 1387-1399.

Sigiura, T., Mizutazi, Y. \& OANa, S. (1963): Fluorine, chlorine, bromine, and iodine in volcanic gases. J. Earth Sci. (Nagoya Univ.) 11, 272-278.

Stoessell, R.K. \& CARPenter, A.B. (1986): Stoichiometric saturation tests of $\mathrm{NaCl}_{1-\mathrm{x}} \mathrm{Br}_{\mathrm{x}}$ and $\mathrm{KCl}_{1-\mathrm{x}} \mathrm{Br}_{\mathrm{x}}$. Geochim. Cosmochim. Acta 50, 1465-1474.
Teertstra, D.K. \& Sherriff, B.L. (1997): Substitutional mechanisms, compositional trends and the end-member formulae of scapolite. Chem. Geol. 136, 233-260.

You, C.F., Butterfield, D.A., Spivack, A.J., Gieskes, J.M., GAmo, T. \& CAMPBELl, A.J. (1994): Boron and halide systematics in submarine hydrothermal systems: effects of phase separation and sedimentary contributions. Earth Planet. Sci. Lett. 123, 227-238.

Received August 17, 2002, revised manuscript February 25, 2003. 